\title{
Ficus deltoidea: A Potential Alternative Medicine for Diabetes Mellitus
}

\author{
Zainah Adam, ${ }^{1}$ Shafii Khamis, ${ }^{1}$ Amin Ismail, ${ }^{2}$ and Muhajir Hamid ${ }^{3}$ \\ ${ }^{1}$ Medical Technology Division, Malaysian Nuclear Agency, Bangi, Selangor 43000 Kajang, Malaysia \\ ${ }^{2}$ Department of Nutrition and Dietetics, Faculty of Medicine and Health Sciences, Universiti Putra Malaysia, \\ Selangor 43400 Serdang, Malaysia \\ ${ }^{3}$ Department of Microbiology, Faculty of Biotechnology and Biomolecular Sciences, Universiti Putra Malaysia, \\ Selangor 43400 Serdang, Malaysia
}

Correspondence should be addressed to Muhajir Hamid, muhajir@biotech.upm.edu.my

Received 13 February 2012; Accepted 4 April 2012

Academic Editor: Pierre Kamtchouing

Copyright (C) 2012 Zainah Adam et al. This is an open access article distributed under the Creative Commons Attribution License, which permits unrestricted use, distribution, and reproduction in any medium, provided the original work is properly cited.

\begin{abstract}
Ficus deltoidea from the Moraceae family has been scientifically proven to reduce hyperglycemia at different prandial states. In this study, we evaluate the mechanisms that underlie antihyperglycemic action of Ficus deltoidea. The results had shown that hot aqueous extract of Ficus deltoidea stimulated insulin secretion significantly with the highest magnitude of stimulation was 7.31-fold $(P<0.001)$. The insulin secretory actions of the hot aqueous extract involved $\mathrm{K}^{+}{ }_{\text {ATP }}$ channel-dependent and $\mathrm{K}^{+}{ }_{\text {ATP }}-$ channel-independent pathway. The extract also has the ability to induce the usage of intracellular $\mathrm{Ca}^{2+}$ to trigger insulin release. The ethanolic and methanolic extracts enhanced basal and insulin-mediated glucose uptake into adipocytes cells. The extracts possess either insulin-mimetic or insulin-sensitizing property or combination of both properties during enhancing glucose uptake into such cells. Meanwhile, the hot aqueous and methanolic extracts augmented basal and insulin-stimulated adiponectin secretion from adipocytes cells. From this study, it is suggested that Ficus deltoidea has the potential to be developed as future oral antidiabetic agent.
\end{abstract}

\section{Introduction}

Type 2 diabetes mellitus is characterized by persistent hyperglycemia resulting from defect of insulin secretion and insulin action [1]. Long-term hyperglycemia is a major factor in development of pathogenesis of diabetic complications $[2,3]$. Currently, type 2 diabetes mellitus is treated with antidiabetic agents such as sulphonylureas, meglitinides, thiazolidinediones groups, and so forth. Although plenty of antidiabetic agents are available, prevalence of the disease remains major global health problem [4]. This could possibly be due to the limitations of these agents such as undesirable side effects [5]. For instance, sulphonylureas treatment was associated with hypoglycemia and weight gain [68]. Meglitinides treatment causes hypoglycemia, rhinitis, bronchitis, and headache [9]. Meanwhile, thiazolidinediones can cause fluid retention, weight gain, anemia, and liver injury $[10,11]$. These limitations have fueled the search for new antidiabetic drugs for treatment of diabetes mellitus.
Stimulation of insulin secretion from pancreatic $\beta$ cells is one of the mechanisms by which antidiabetic agents reduce hyperglycemia $[12,13]$. The secreted insulin then facilitates glucose uptake in insulin-sensitive cells such as muscle, liver, and adipocytes, hence reduces hyperglycemia [14]. Besides, augmentation of adiponectin secretion from adipocytes cells also has been well accepted as antidiabetic mechanism. This adipocyte-derived factor has been reported to improve insulin sensitivity in skeletal muscle and liver [15-17] resulting in stimulation of glucose utilization and fatty acid oxidation [18], enhancement of glucose uptake through the increment of expression and translocation of GLUT4 [19], suppression of gluconeogenesis in the liver [20] and enhancement of insulin signaling in skeletal muscle [21].

Ficus deltoidea, from the Moraceae family, is one of the common medicinal plants in Malaysia. It has been used to relieve headache, fever, and toothache. Decoction of the whole plant has been used as herbal drink by women after 
birth to strengthen the uterus $[22,23]$. Based on ethnobotanical approaches, this plant has been claimed to have antidiabetic properties [22]. Few scientific studies were done and confirmed the antidiabetic activity of this plant. Acute treatment of $F$. deltoidea extracts reduced hyperglycemia in normal and diabetic rats at different prandial states [2426]. Following 15-day treatment, hot aqueous extract of F. deltoidea stimulated insulin release and reduced fasting hyperglycemia [27]. Elucidation of antihyperglycemic mechanisms demonstrated that this plant enhanced basal and insulin-stimulated glucose uptake into liver cells [28] and reduced the rate of glucose absorption from small intestine by inhibiting intestine sucrase activity [29]. The present study was performed to find other possible antidiabetic mechanisms of $F$. deltoidea, if any, by evaluating the potential of this plant to stimulate insulin secretion from pancreatic $\beta$ cells, to enhance glucose uptake into adipocyte cells, and to augment adiponectin secretion from adipocyte cells.

\section{Methodology}

2.1. Chemicals and Reagents. BRIN BD11 cell line was a gift from the Animal Cell Culture Laboratory, Faculty of Biotechnology and Biomolecular Sciences, Universiti Putra Malaysia. 3T3F442A preadipocytes were purchased from the European Collection of Cell Cultures (ECACC, Salisbury, UK). All cell culture supplements were purchased from Invitrogen, USA. Ethanol and methanol were purchased from J. T. Baker Chemical Co. Sodium chloride $(\mathrm{NaCl})$, potassium chloride $(\mathrm{KCl})$, calcium chloride $\left(\mathrm{CaCl}_{2}\right)$, potassium dihydrogen phosphate $\left(\mathrm{KH}_{2} \mathrm{PO}_{4}\right)$, magnesium sulphate $\left(\mathrm{MgSO}_{4}\right)$, sodium hydrogen carbonate $\left(\mathrm{NaHCO}_{3}\right)$, HEPES, sodium dodecyl sulphate (SDS), 3-(4,5-dimethylthiazol-2yl)-2,5-diphenyltetrazolium bromide (MTT), bovine insulin, ammonium hydroxide $\left(\mathrm{NH}_{4} \mathrm{OH}\right)$, dimethylsulphoxide (DMSO), glibenclamide, isobutylmethylxanthine (IBMX), tolbutamide, diazoxide, verapamil, and D-glucose were purchased from Sigma Chemical Co. (St. Louise, MO, USA). Ultima Gold LLT was purchased from PerkinElmer (USA). 2-Deoxy- $\left[1-{ }^{3} \mathrm{H}\right]$-glucose was purchased from GE Healthcare (USA). Rosiglitazone maleate (Avandia) was purchased from a local pharmacy.

2.2. Plant Materials and Extraction Procedure. Plants of $F$. deltoidea were collected at the Sungai Tengi Selatan, Selangor, Malaysia. The plants were identified by a taxonomist from the Biodiversity Unit of the Institute of Bioscience, Universiti Putra Malaysia. A specimen (SK1467/07) was deposited at the herbarium of the above institute. The leaves of $F$. deltoidea were oven dried at $45^{\circ} \mathrm{C}$ and ground to a fine powder. Hot aqueous extracts were prepared by boiling the powdered sample in distilled water for 3 hours $(100 \mathrm{~g} / \mathrm{L})$ by changing the water every hour. The combined suspension was filtered using Whatman filter paper no. 54 and freezedried to give the powdered form. Ethanolic extract was prepared by soaking the powder in $95 \%$ ethanol for 3 days $(100 \mathrm{~g} / \mathrm{L})$ at room temperature by changing solvent daily. The combined suspension was filtered using Whatman filter paper no. 54 and evaporated to dryness under pressure at $30^{\circ} \mathrm{C}$ to give an ethanolic extract. Methanolic extract was prepared by soaking the powder in $95 \%$ methanol for 3 days $(100 \mathrm{~g} / \mathrm{L})$ at room temperature by changing solvent daily. The combined suspension was filtered using Whatman filter paper no. 54 and evaporated to dryness under pressure at $30^{\circ} \mathrm{C}$ to give a methanolic extract. The yield of the extract was found to be $21 \mathrm{~g}, 17 \mathrm{~g}$, and $19 \mathrm{~g}$ for hot aqueous, ethanolic, and methanolic extract, respectively.

2.3. Cell Viability Assay. The viability of all cell lines in the presence of $F$. deltoidea hot aqueous, ethanolic, and methanolic extracts was conducted according to the method of Mosmann [30] and Carmichael et al. [31]. BRIN BD11 cell line was maintained in the Roswell Park Memorial Institute (RPMI) 1640 medium and 3T3F442A preadipocytes were maintained in Dulbecco's modified Eagle's medium (DMEM). Complete culture medium was supplemented with $10 \% \quad(\mathrm{v} / \mathrm{v})$ foetal bovine serum (FBS) and $1 \%$ $(\mathrm{v} / \mathrm{v})$ antibiotic solution $(10,000$ units/mL penicillin and $10 \mathrm{mg} / \mathrm{mL}$ streptomycin) at $37^{\circ} \mathrm{C}$ humidified with $5 \% \mathrm{CO}_{2}$. The confluent cells were seeded at concentration of $1.5 \times$ $10^{5}$ cells/well onto a sterile 96-well plate and incubated at $37^{\circ} \mathrm{C}$ overnight. Cells were further incubated at $37^{\circ} \mathrm{C}$ for 72 hours in the absence or presence of F. deltoidea extracts $(10-1000 \mu \mathrm{g} / \mathrm{mL})$ and glibenclamide $(10-2000 \mu \mathrm{M})$. Following the required incubation period, $20 \mu \mathrm{L}$ of $5 \mathrm{mg} / \mathrm{mL}$ of 3-(4,5-dimethylthiazol-2-yl)2,5-diphenyltetrazolium bromide (MTT) was added to each well and incubated for 4 hours. Subsequently, the media from each well was then gently aspirated and $100 \mu \mathrm{L}$ of dimethylsulphoxide (DMSO) was added to dissolve the formazan crystals. Plates were shaken for 5 seconds, and absorbance was measured at $570 \mathrm{~nm}$ using the Anthos microplate reader (Beckman Coulter, USA).

2.4. Insulin Secretion Assay. Insulin secreting activity of $F$. deltoidea was evaluated using BRIN-BD11 cells. The generation and basic characteristics of this glucose-responsive insulin-secreting cell line have been described elsewhere [32]. BRIN BD11 cell line was maintained in RPMI 1640 medium supplemented with $10 \%(\mathrm{v} / \mathrm{v})$ FBS and $1 \%(\mathrm{v} / \mathrm{v})$ antibiotic solution (10,000 units/mL penicillin and $10 \mathrm{mg} / \mathrm{mL}$ streptomycin) at $37^{\circ} \mathrm{C}$ humidified with $5 \% \mathrm{CO}_{2}$. Insulin secretion assay was conducted according to the method of Gray and Flatt [33] with brief modifications. Cells were seeded at a concentration of $2.5 \times 10^{5}$ cells/well in a 12-well plate and incubated at $37^{\circ} \mathrm{C}$ overnight to allow attachment prior to test. The next day, cells were washed thrice with the KrebsRinger bicarbonate buffer (KRB) and preincubated with this $\mathrm{KRB}$ for 40 minutes at $37^{\circ} \mathrm{C}$. Cells were further incubated for 1 hours with KRB (negative control) KRB containing F. deltoidea hot aqueous, ethanolic, and methanolic extracts (10$1000 \mu \mathrm{g} / \mathrm{mL}) \mathrm{KRB}$ containing glibenclamide (10-2000 $\mu \mathrm{M})$. All evaluations were performed at $2 \mathrm{mM}$ glucose. Insulin concentration was determined using Rat Insulin ELISA Kits (Mercodia AB, Sweden). 
2.5. Elucidation of Insulin Secretion Mechanisms. F. deltoidea extracts that showed tremendous insulin secretion activity were further evaluated for determination of their insulin secretory mechanisms. The evaluations were conducted according to the method of Hannan et al. [34]. Extracts were incubated with modulators that are known to affect secondary messenger pathway in pancreatic $\beta$-cells such as insulin secretagogue (isobutylmethylxanthine (IBMX) and tolbutamide), insulin secretion inhibitor (diazoxide and verapamil), and potassium chloride $(\mathrm{KCl})$ at depolarizing concentration. Cells were seeded at a concentration of $2.5 \times$ $10^{5}$ cells/well in a 12-well plates and incubated overnight at $37^{\circ} \mathrm{C}$ to allow attachment prior to test. The next day, cells were washed thrice with KRB and preincubated with KRB for 40 minutes at $37^{\circ} \mathrm{C}$. Further incubation was done for 1 hour with KRB containing $F$. deltoidea extract in the absence and presence of $100 \mu \mathrm{M}$ of IBMX, $200 \mu \mathrm{M}$ of tolbutamide, $300 \mu \mathrm{M}$ of diazoxide, $50 \mathrm{mM}$ of verapamil, and $30 \mathrm{mM}$ of $\mathrm{KCl}$. All evaluations were performed at $2 \mathrm{mM}$ glucose. Insulin concentration was determined using Rat Insulin ELISA Kits (Mercodia AB, Sweden).

2.6. Glucose Uptake Assay. 3T3F442A preadipocytes was maintained in DMEM supplemented with $10 \%(\mathrm{v} / \mathrm{v})$ FBS and $1 \%(\mathrm{v} / \mathrm{v})$ antibiotic solution $(10,000$ units $/ \mathrm{mL}$ penicillin and $10 \mathrm{mg} / \mathrm{mL}$ streptomycin) at $37^{\circ} \mathrm{C}$ humidified with $5 \%$ $\mathrm{CO}_{2}$. The 3T3F442A preadipocytes were differentiated into adipocytes spontaneously when reach confluency. At this time culture medium was supplemented with $5 \mu \mathrm{g} / \mathrm{mL}$ insulin. Glucose uptake assay was done according to Liu et al. [35] with some modifications. Briefly, confluent cells were seeded at a concentration of $2 \times 10^{5}$ cells/well in a 12well plate and left overnight at $37^{\circ} \mathrm{C}$ to allow attachment prior to test. The next day, cells were washed thrice with serum-free DMEM and preincubated with this medium for 2 hours at $37^{\circ} \mathrm{C}$. After starvation period, cells were washed thrice with the Krebs-Ringer bicarbonate buffer (KRB). Cells were further incubated for 30 minutes at $37^{\circ} \mathrm{C}$ with various concentrations of $F$. deltoidea extracts (10$1000 \mu \mathrm{g} / \mathrm{mL}$ ) either alone or in combination with $100 \mathrm{nM}$ insulin. Rosiglitazone maleate (Avandia) was used as positive control. To initiate glucose uptake reaction, 2-deoxy- $\left[1-{ }^{3} \mathrm{H}\right]-$ glucose $(1 \mu \mathrm{Ci} / \mathrm{mL})$ diluted in $0.1 \mathrm{mM} \mathrm{D}$-glucose solution was added to each well and incubated further for 60 minutes at $37^{\circ} \mathrm{C}$. After incubation, cells were washed thrice with ice-cold KRB buffer and solubilized with $0.1 \%$ sodium deodecyl sulphate (SDS) dissolved in phosphate buffer, $\mathrm{pH}$ 7.4. The content of each well was transferred into scintillation vials, and $15 \mathrm{~mL}$ of scintillation cocktail, Ultima Gold LLT, was added. The radioactivity incorporated into the cells was measured using liquid scintillation counter (Hewlett Packard, USA).

2.7. Adiponectin Secretion Assay. The potential of F. deltoidea to stimulate adiponectin secretion was evaluated in 3T3F442A adipocyte cells. Adiponectin secretion assay was conducted according to the method of Roffey et al. [36], with brief modifications. Confluent cells were seeded at a concentration of $2 \times 10^{5}$ cells/well in 12-well plate and left overnight at $37^{\circ} \mathrm{C}$ humidified with $5 \% \mathrm{CO}_{2}$ to allow attachment prior to test. The next day, cells were washed thrice with serum-free DMEM and pre-incubated with this medium for 2 hours at $37^{\circ} \mathrm{C}$. After starvation period, cells were washed thrice with the Krebs-Ringer bicarbonate buffer (KRB). Cells were further incubated for 60 minutes at $37^{\circ} \mathrm{C}$ with various concentrations of $F$. deltoidea extracts (10$1000 \mu \mathrm{g} / \mathrm{mL}$ ) either alone or in combination with $100 \mathrm{nM}$ insulin. Rosiglitazone maleate was used as positive controls. Adiponectin secreted in the solution was measured using Rat Adiponectin ELISA Assay Kits (BioVision, USA).

2.8. Statistical Analysis. Results are expressed as mean \pm standard deviation for a given number of observations. Statistical analyses were performed using GraphPad Prism Software version 4.0 (serial no. GpW4-015977-RHB-3678). The data were analyzed using one-way analysis of variance (ANOVA), followed by Tukey's post hoc test. The group means were considered significantly different at the level of $P<0.05$.

\section{Results}

3.1. Cells Viability in the Presence of F. deltoidea Extracts. The effects of F. deltoidea extracts and glibenclamide on BRIN BD11 cell viability are shown in Table 1 . All extracts' and glibenclamide, at particular, concentrations reduced BRIN BD11 cells viability significantly. Ethanolic and methanolic extracts at concentrations of 500 and $1000 \mu \mathrm{g} / \mathrm{mL}$ as well as glibenclamide at concentration of $2000 \mu \mathrm{M}$ reduced the viability of BRIN BD11 cells to less than $50 \%$. In 3T3F442A adipocytes, all $F$. deltoidea extracts reduced cell viability significantly at all concentrations evaluated (Table 2). However, no extract reduced cell viability to less than $50 \%$. Rosiglitazone maleate exhibited a reduction in cell viability at concentration 7 to $140 \mu \mathrm{M}$, and it was shown that reduction at the highest concentration was more than $50 \%$.

3.2. Insulin Secreting Activity of $F$. deltoidea Extracts. Effects of $F$. deltoidea extracts and glibenclamide on insulin secretion from BRIN BD11 cells are shown in Figure 1. Hot aqueous extract exhibited a stepwise stimulatory effect on insulin secretion at $2 \mathrm{mM}$ glucose. Significant stimulation was observed at concentrations 50,100, 500, and $1000 \mu \mathrm{g} / \mathrm{mL}$ which evoked a $2.61-(P<0.001), 3.68-(P<0.001)$, 4.38$(P<0.001)$ and $7.31-(P<0.001)$ fold of stimulation, respectively, compared to control. In the presence of ethanolic extract, a significant stimulation of insulin secretion (1.27-fold; $P<0.001)$ was only observed at concentration $100 \mu \mathrm{g} / \mathrm{mL}$. Meanwhile, the methanolic extract significantly stimulated insulin secretion at all concentrations evaluated with the magnitude of insulin secretion 1.24-fold $(P<$ $0.001), 1.41$-fold $(P<0.001), 1.34$-fold $(P<0.001), 1.36$ fold $(P<0.001)$, and 1.36 -fold $(P<0.001)$ obtained at concentrations of $10,50,100,500$, and $1000 \mu \mathrm{g} / \mathrm{mL}$, respectively. Glibenclamide had significantly stimulated insulin secretion at concentrations of $1000 \mu \mathrm{M}(1.80$-fold; $P<0.001)$ and 
TABLE 1: Effect of F. deltoidea extracts and glibenclamide on BRIN BD11 viability.

\begin{tabular}{lcccccc}
\hline $\begin{array}{l}\text { F. deltoidea } \\
\text { extracts }\end{array}$ & Control & $10 \mu \mathrm{g} / \mathrm{mL}$ & $50 \mu \mathrm{g} / \mathrm{mL}$ & $100 \mu \mathrm{g} / \mathrm{mL}$ & $500 \mu \mathrm{g} / \mathrm{mL}$ & $1000 \mu \mathrm{g} / \mathrm{mL}$ \\
\hline Hot aqueous & $100.00 \pm 2.62$ & $95.30 \pm 4.37$ & $95.54 \pm 4.98$ & $95.66 \pm 10.19$ & $\begin{array}{c}99.27 \pm 6.19 \\
91.29 \pm 2.69 \\
(8.71 \%)^{*}\end{array}$ \\
Ethanolic & $100.00 \pm 4.84$ & $\begin{array}{c}92.80 \pm 1.54^{* * *} \\
(7.20 \%)\end{array}$ & $\begin{array}{c}89.60 \pm 3.30^{* * *} \\
(10.40 \%)\end{array}$ & $\begin{array}{c}85.73 \pm 1.56^{* * *} \\
(14.27 \%)\end{array}$ & $\begin{array}{c}38.88 \pm 0.94^{* * *} \\
(61.12 \%)\end{array}$ & $\begin{array}{c}36.46 \pm 1.21^{* * *} \\
(63.54 \%)\end{array}$ \\
Methanolic & $100.00 \pm 6.38$ & $99.32 \pm 3.39$ & $97.42 \pm 5.62$ & $101.38 \pm 2.79$ & $\begin{array}{c}41.80 \pm 2.62^{* * *} \\
(58.20 \%)\end{array}$ & $\begin{array}{c}34.42 \pm 0.75^{* * *} \\
(65.58 \%)\end{array}$ \\
\hline Glibenclamide & $100.00 \pm 7.24$ & $95.12 \pm 7.33$ & $97.46 \pm 7.79$ & $97.96 \pm 9.03$ & $\begin{array}{r}59.51 \pm 12.76^{* * *} \\
(40.49 \%)\end{array}$ & $\begin{array}{r}32.71 \pm 2.79^{* * *} \\
(67.29 \%)\end{array}$ \\
\hline
\end{tabular}

Notes: Cells were incubated for 72 hours in the presence of various concentrations of $F$. deltoidea extracts $(10-1000 \mu \mathrm{g} / \mathrm{mL})$ and glibenclamide $(10-2000 \mu \mathrm{M})$. Values are expressed as means \pm standard deviations $(n=8)$ of percentage of cell viability from three independent assays. ${ }^{*} P<0.05$; ${ }^{* * *} P<0.001$ compared with control. Values between brackets indicate the percentage of cell viability reduction.

TABLE 2: Effect of F. deltoidea extracts and rosiglitazone maleate on 3T3F442A adipocyte viability.

\begin{tabular}{|c|c|c|c|c|c|c|}
\hline \multirow{2}{*}{$\begin{array}{l}\text { F. deltoidea } \\
\text { extracts }\end{array}$} & \multicolumn{6}{|c|}{ Cell viability (\%) } \\
\hline & Control & $10 \mu \mathrm{g} / \mathrm{mL}$ & $50 \mu \mathrm{g} / \mathrm{mL}$ & $100 \mu \mathrm{g} / \mathrm{mL}$ & $500 \mu \mathrm{g} / \mathrm{mL}$ & $1000 \mu \mathrm{g} / \mathrm{mL}$ \\
\hline Hot aqueous & $100.00 \pm 9.42$ & $\begin{array}{c}90.75 \pm 14.33^{* *} \\
(9.25 \%)\end{array}$ & $\begin{array}{c}70.59 \pm 4.23^{* * *} \\
(29.41 \%)\end{array}$ & $\begin{array}{c}66.25 \pm 2.52^{* * *} \\
(33.75 \%)\end{array}$ & $\begin{array}{c}55.26 \pm 3.51^{* * *} \\
(44.74 \%)\end{array}$ & $\begin{array}{c}55.03 \pm 1.51 \text { *** } \\
(44.97 \%)\end{array}$ \\
\hline Ethanolic & $100.00 \pm 1.10$ & $\begin{array}{c}86.92 \pm 3.14^{* * *} \\
(13.08 \%)\end{array}$ & $\begin{array}{c}72.93 \pm 1.34^{* * *} \\
(27.07 \%)\end{array}$ & $\begin{array}{c}69.60 \pm 1.56^{* * * *} \\
(30.40 \%)\end{array}$ & $\begin{array}{c}51.06 \pm 0.60^{* * *} \\
(48.94 \%)\end{array}$ & $\begin{array}{c}55.07 \pm 6.14^{* * *} \\
\quad(44.93 \%)\end{array}$ \\
\hline \multirow[t]{2}{*}{ Methanolic } & $100.00 \pm 1.10$ & $\begin{array}{c}88.65 \pm 3.42^{* * *} \\
(11.35 \%)\end{array}$ & $\begin{array}{c}72.54 \pm 1.45^{* * * *} \\
(27.46 \%)\end{array}$ & $\begin{array}{c}70.99 \pm 1.65^{* * *} \\
(29.01 \%)\end{array}$ & $\begin{array}{c}62.61 \pm 4.01^{* * *} \\
(37.39 \%)\end{array}$ & $\begin{array}{c}51.55 \pm 1.00^{* * *} \\
\quad(48.45 \%)\end{array}$ \\
\hline & Control & $3.5 \mu \mathrm{M}$ & $7 \mu \mathrm{M}$ & $35 \mu \mathrm{M}$ & $70 \mu \mathrm{M}$ & $140 \mu \mathrm{M}$ \\
\hline $\begin{array}{l}\text { Rosiglitazone } \\
\text { maleate }\end{array}$ & $100.00 \pm 7.05$ & $91.57 \pm 6.58$ & $\begin{array}{c}77.10 \pm 7.31^{* * *} \\
(22.90 \%)\end{array}$ & $\begin{array}{c}71.97 \pm 6.53^{* * *} \\
(28.03 \%)\end{array}$ & $\begin{array}{c}54.01 \pm 7.41^{* * *} \\
(45.99 \%)\end{array}$ & $\begin{array}{l}49.51 \pm 5.74^{* * *} \\
\quad(50.49 \%)\end{array}$ \\
\hline
\end{tabular}

Notes: Cells were incubated for 72 hours in the presence of various concentrations of $F$. deltoidea extracts $(10-1000 \mu \mathrm{g} / \mathrm{mL})$ and rosiglitazone maleate $(3.5-$ $140 \mu \mathrm{M})$. Values expressed as percentage of means \pm standard deviations $(n=8)$ of the cells viability from three independent assays. ${ }^{* *} P<0.01 ;{ }^{* * *} P<$ 0.001 compared with control. Values between brackets indicate percentage of cell viability reduction.

$2000 \mu \mathrm{M}$ (1.73-fold; $P<0.001)$. The former concentration was used as standard reference because it shows the highest magnitude of stimulation following a dose-response evaluation.

3.3. Insulin Secretion Mechanisms of Hot Aqueous Extract. The influence of insulin secretion modulators on the effect of $1000 \mu \mathrm{g} / \mathrm{mL}$ hot aqueous extract on insulin secretion from BRIN BD11 cells is shown in Figure 2. All evaluations were done at basal glucose concentration $(2 \mathrm{mM})$. It was shown that $1000 \mu \mathrm{g} / \mathrm{mL}$ of hot aqueous extract significantly stimulated basal insulin secretion (untreated control) by 5.57fold $(P<0.001)$. All modulators showed no effect on basal insulin secretion except $30 \mathrm{mM} \mathrm{KCl}$ which stimulated basal insulin secretion by 3.60 -fold $(P<0.001)$. Insulin-releasing effect of $1000 \mu \mathrm{g} / \mathrm{mL}$ of hot aqueous was potentiated in the presence of all modulators except for $50 \mathrm{mM}$ verapamil which exhibited similar magnitude of secretion between the absence and presence of $1000 \mu \mathrm{g} / \mathrm{mL}$ of hot aqueous extract. The magnitudes of potentiation were 3.04-fold $(P<0.001)$, 6.30-fold $(P<0.001)$, 3.95-fold $(P<0.001)$, and 2.60fold $(P<0.001)$ in the presence of $30 \mathrm{mM}$ of $\mathrm{KCl}, 200 \mu \mathrm{M}$ of tolbutamide, $100 \mu \mathrm{M}$ of IBMX, and $300 \mu \mathrm{M}$ of diazoxide, respectively. Combinations of $1000 \mu \mathrm{g} / \mathrm{mL}$ of hot aqueous extract with $30 \mathrm{mM} \mathrm{KCl}$ and tolbutamide had escalated the insulin-releasing effect of the extract when compared to the extract alone. The magnitude of escalations were 1.96-fold $(P<0.001)$ and 1.56 -fold $(P<0.001)$, respectively. In contrast, combinations of $1000 \mu \mathrm{g} / \mathrm{mL}$ of hot aqueous extract with diazoxide and verapamil had inhibited insulin-releasing effect of the extract with magnitudes of inhibition 0.49fold $(P<0.001)$ and 0.79 -fold $(P<0.001)$, respectively. Meanwhile the IBMX has no effect on insulin secretion causes by $1000 \mu \mathrm{g} / \mathrm{mL}$ of hot aqueous extract.

3.4. Glucose Uptake Activity of F. deltoidea Extracts. Table 3 shows the effects of $F$. deltoidea extracts on glucose uptake activity in 3T3F442A adipocytes. Insulin (100 nM) alone enhanced glucose uptake by 1.55 -fold $(P<0.001)$ relative to control. Hot aqueous extract has no effect on glucose uptake activity in 3T3F442A adipocytes. Ethanolic extract increased basal and insulin-mediated glucose uptake in a concentration-dependent manner. Basal glucose uptake was enhanced at concentrations of 500 , and $1000 \mu \mathrm{g} / \mathrm{mL}$. Enhancement effect produced by the later concentration was 1.32-fold $(P<0.01)$ higher than that of $100 \mathrm{nM}$ insulin alone. Insulin-mediated glucose uptake was enhanced at concentrations of 100, 500, and $1000 \mu \mathrm{g} / \mathrm{mL}$. Enhancement 

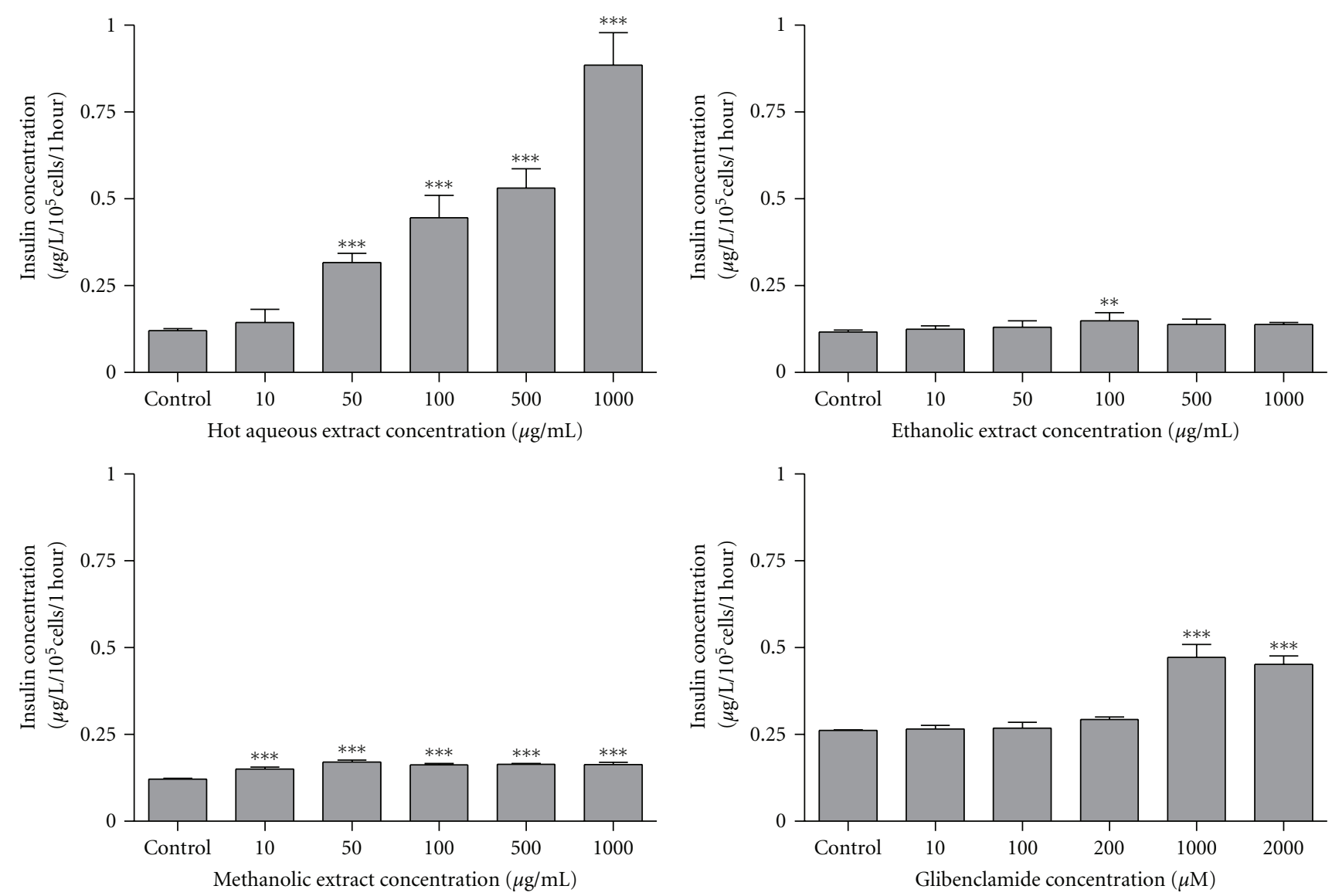

FIGURE 1: Effect of F. deltoidea extracts and glibenclamide on insulin secretion activity from BRIN BD11 cells. Values are expressed as mean \pm standard deviation $(n=4$ to 8$)$. ${ }^{* *} P<0.01$ and ${ }^{* * *} P<0.01$ compared with control.

effect produced by the highest concentration was 1.29fold $(P<0.05)$ higher than that of $100 \mathrm{nM}$ insulin. The methanolic extract also exhibited concentration-dependent enhancement of glucose uptake. Basal uptake was significantly enhanced at concentrations of 500 and $1000 \mu \mathrm{g} / \mathrm{mL}$. The enhancement by the latter concentration was 1.27 -fold $(P<0.05)$ higher than that of $100 \mathrm{nM}$ insulin alone. Insulinmediated uptake was significantly enhanced at concentrations of 100,500 , and $1000 \mu \mathrm{g} / \mathrm{mL}$. Rosiglitazone maleate at concentrations of $35 \mu \mathrm{M}$ and $70 \mu \mathrm{M}$ was used as positive control to challenge the effects of $F$. deltoidea on basal and insulin-mediated glucose uptake in 3T3F442A adipocytes, respectively. These concentrations were chosen because they shows highest magnitude of enhancement following a doseresponse evaluation.

3.5. Adiponectin Secreting Activity of F. deltoidea Extracts. Table 4 shows the effect of $F$. deltoidea extracts on adiponectin secretion from 3T3F442A adipocytes. $100 \mathrm{nM}$ insulin stimulated adiponectin secretion by 1.64 -fold relative to control. Hot aqueous extract augmented adiponectin secretion in a concentration-dependent manner. Basal adiponectin secretion was significantly increased at concentrations of 500 and $1000 \mu \mathrm{g} / \mathrm{mL}$, respectively. Increments of adiponectin secretion by such concentrations were 1.26 -fold $(P<0.001)$ and 1.56-fold $(P<0.001)$ higher than that of $100 \mathrm{nM}$ insulin alone, respectively. Likewise, insulin-stimulated adiponectin secretion was significantly increased at concentrations of 500 and $1000 \mu \mathrm{g} / \mathrm{mL}$. The increment effect by the latter concentration was 1.27 -fold higher than that of $100 \mathrm{nM}$ insulin alone. For both concentrations of the extracts, there were no differences in adiponectin secretion between basal and insulin-stimulated state. Meanwhile, the ethanolic extract of $F$. deltoidea has no effect on adiponectin secretion from 3T3F442A adipocytes. Similar to hot aqueous extract, the methanolic extract increased adiponectin secretion in a concentration-dependent manner. Basal adiponectin secretion was significantly increased at concentrations of 500, and $1000 \mu \mathrm{g} / \mathrm{mL}$. Under insulin-stimulated state, methanolic extract at concentrations of $10,50,100,500$ and $1000 \mu \mathrm{g} / \mathrm{mL}$ increased adiponectin secretion. Rosiglitazone maleate at concentrations of $70 \mu \mathrm{M}$ and $35 \mu \mathrm{M}$ was used as positive controls to challenge effect of $F$. deltoidea extracts on basal and insulin-stimulated adiponectin secretion, respectively. These concentrations were chosen because they produces the highest stimulation effect after a dose response evaluation. The enhancement of adiponectin secretion by $F$. deltoidea hot aqueous and methanolic extracts was lesser than that of the positive controls. 
TABLE 3: Effect of F. deltoidea extracts on glucose uptake in 3T3F442A adipocytes.

Fold of glucose uptake against control

\begin{tabular}{|c|c|c|c|c|c|c|c|c|c|c|}
\hline \multirow{2}{*}{$\begin{array}{l}\text { Extract } \\
\text { concentration } \\
(\mu \mathrm{g} / \mathrm{mL})\end{array}$} & \multirow[t]{2}{*}{ Control } & \multirow[t]{2}{*}{$\begin{array}{l}100 \mathrm{nM} \\
\text { insulin }\end{array}$} & \multicolumn{2}{|c|}{ Hot aqueous } & \multicolumn{2}{|c|}{ Ethanolic } & \multicolumn{2}{|c|}{ Methanolic } & \multicolumn{2}{|c|}{ Rosiglitazone malate } \\
\hline & & & Basal & $\begin{array}{l}\text { Insulin- } \\
\text { mediated }\end{array}$ & Basal & $\begin{array}{l}\text { Insulin- } \\
\text { mediated }\end{array}$ & Basal & $\begin{array}{l}\text { Insulin- } \\
\text { mediated }\end{array}$ & Basal & $\begin{array}{l}\text { Insulin- } \\
\text { mediated }\end{array}$ \\
\hline 10 & \multirow{5}{*}{1.00} & \multirow{5}{*}{$1.55^{* * *}$} & 0.88 & 1.00 & 1.11 & 1.24 & 1.02 & 1.16 & \multirow{5}{*}{$\begin{array}{c}35 \mathrm{~m} \\
1.99^{* * *}\end{array}$} & \multirow{5}{*}{$\begin{array}{r}70 \mu \mathrm{M} \\
2.27^{* * *}\end{array}$} \\
\hline 50 & & & 0.86 & 0.92 & 1.14 & 1.22 & 1.15 & 1.18 & & \\
\hline 100 & & & 1.13 & 1.45 & 1.18 & $1.35^{*}$ & 1.32 & $1.25^{*}$ & & \\
\hline 500 & & & 1.49 & 1.29 & $1.61^{* * *}$ & $1.69^{* * *}$ & $1.71^{* * *}$ & $1.54^{* * *}$ & & \\
\hline 1000 & & & 1.28 & 1.32 & $\begin{array}{c}2.04^{* * *} \\
\quad \bullet\end{array}$ & $\begin{array}{c}1.99^{* * *} \\
\bullet\end{array}$ & $\begin{array}{c}1.97^{* * *} \\
\bullet\end{array}$ & $1.68^{* * *}$ & & \\
\hline
\end{tabular}

Values expressed as means \pm standard deviations from three independent experiments.

${ }^{*} P<0.05,{ }^{* * *} P<0.001$ compared with control incubation.

$\bullet P<0.05, \bullet P<0.01$ compared to $100 \mathrm{nM}$ insulin.

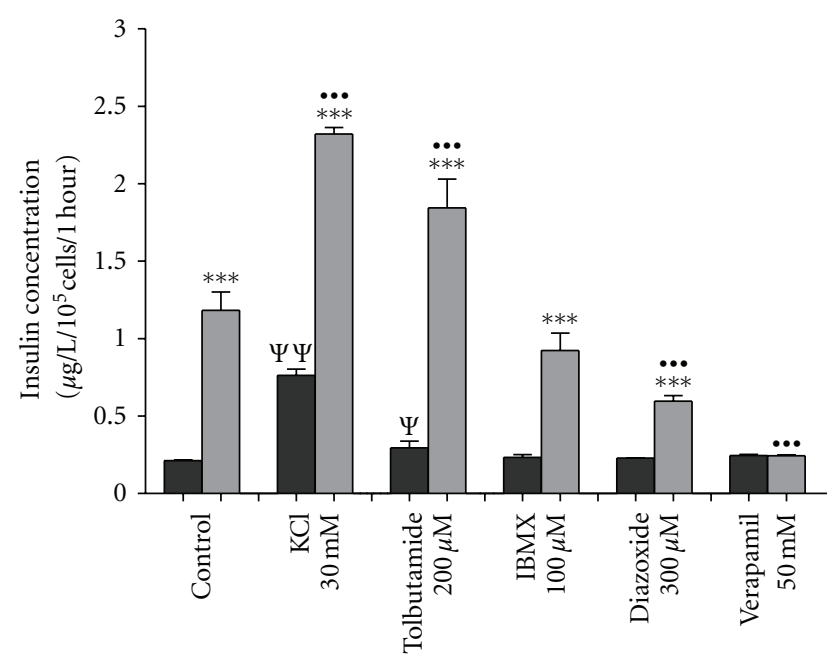

Without hot aqueous extract

With hot aqueous extract $1000 \mu \mathrm{g} / \mathrm{mL}$

Figure 2: The influence of insulin secretion modulators on the effect of $1000 \mu \mathrm{g} / \mathrm{mL}$ hot aqueous extract on insulin secretion from BRIN BD11 cells. Values are expressed as mean \pm standard deviation $(n=4) .{ }^{* * *} P<0.001$ compared with incubation without hot aqueous extract in the respective treatment group. ${ }^{\cdots} P<0.001$ compared with control treated with hot aqueous extract. ${ }^{\Psi} P<0.05$; ${ }^{\Psi \Psi} P<0.01$ compared with untreated control.

\section{Discussions}

The present study reports for the first time the insulin secreting, glucose uptake, and adiponectin secretion properties of F. deltoidea plant. These suggests that there is possibility of presence of antidiabetic compounds in the F. deltoidea plant which exert antidiabetic action through stimulation of insulin secretion from pancreatic $\beta$ cells, enhancement of glucose uptake by adipocytes cells, and stimulation of adiponectin secretion in adipocytes cells. Previous research had reported that flavonoids stimulated insulin secretion from pancreatic $\beta$ cells [37], stimulated adiponectin secretion in adipocytes cells [16], and enhanced glucose uptake into adipocytes cells in an insulin-mimetic manner [38]. In addition, Eucalyptus globules plants which possess insulin secreting activity have been reported to contain flavonoids and tannins [39]. Phytochemical screening of F. deltoidea revealed the presence of high amount of flavonoids and tannins [40]. Thus, there is possibility that these secondary metabolites account for the observed pharmacologic effects of the F. deltoidea plant.

The viability of BRIN BD11 cell in the presence of $F$. deltoidea extracts at various concentrations was evaluated using MTT assay. In this assay, the yellow tetrazolium salt, MTT, is reduced by the mitochondrial enzymes, succinate dehydrogenase, to form insoluble purple formazan crystals which are solubilized by the addition of a detergent [30]. The color produced then can be measured spectrophotometrically at $570 \mathrm{~nm} \mathrm{[31].} \mathrm{MTT} \mathrm{reduction} \mathrm{was} \mathrm{proportional}$ to cell viability [30]. Following 72-hour treatment, all extracts at particular concentrations reduced BRIN BD11 and 3T3F442A adipocyte cells significantly. According to Elmore et al. [41], the highest concentration of a test agent in cytotoxicity evaluation should be $1000 \mu \mathrm{g} / \mathrm{mL}$ or $1000 \mu \mathrm{M}$. If none of the concentrations of test agents exhibited cytotoxic effect in excess of $50 \%$ of cell populations, the test agent is considered nontoxic against the tested cell line. In the present study, ethanolic and methanolic extracts at concentrations of 500 and $1000 \mu \mathrm{g} / \mathrm{mL}$ reduce the viability of BRIN BD11 cells to less than $50 \%$. Thus, both extracts were considered toxic against BRIN BD11 cells [41].

Insulin is an anabolic hormone secreted by pancreatic $\beta$ cells in response to elevation of blood glucose concentration especially after meal $[42,43]$. This hormone maintains body glucose homeostasis by regulating metabolism of carbohydrate, lipid, and protein [44]. Insulin reduced hyperglycemia by facilitating glucose disposal from blood circulation into insulin-responsive cells such as muscle, adipose, and liver $[45,46]$. The secretion of insulin involved two major signaling pathways, $\mathrm{K}^{+}$ATP channel-dependent and $\mathrm{K}^{+}$ATP channel-independent pathways $[42,47]$. The former is responsible for the first-phase glucose-stimulated insulin secretion whereas combination of both pathways responsible 
TABLE 4: Effect of F. deltoidea extracts on adiponectin secretion from 3T3F442A adipocytes.

Fold of glucose uptake against control

\begin{tabular}{|c|c|c|c|c|c|c|c|c|c|c|}
\hline \multirow{2}{*}{$\begin{array}{l}\text { Extract } \\
\text { concentration } \\
(\mu \mathrm{g} / \mathrm{mL})\end{array}$} & \multirow[t]{2}{*}{ Control } & \multirow{2}{*}{$\begin{array}{l}100 \mathrm{nM} \\
\text { insulin }\end{array}$} & \multicolumn{2}{|c|}{ Hot aqueous } & \multicolumn{2}{|c|}{ Ethanolic } & \multicolumn{2}{|c|}{ Methanolic } & \multicolumn{2}{|c|}{ Rosiglitazone malate } \\
\hline & & & Basal & $\begin{array}{l}\text { Insulin- } \\
\text { mediated }\end{array}$ & Basal & $\begin{array}{l}\text { Insulin- } \\
\text { mediated }\end{array}$ & Basal & $\begin{array}{l}\text { Insulin- } \\
\text { mediated }\end{array}$ & Basal & $\begin{array}{l}\text { Insulin- } \\
\text { mediated }\end{array}$ \\
\hline 10 & & & 1.01 & 0.93 & 1.06 & 0.99 & 1.11 & $1.45^{* * *}$ & & \\
\hline 50 & & & 1.16 & 1.05 & 0.99 & 1.04 & 1.09 & $1.46^{* * *}$ & & \\
\hline 100 & 1.00 & $1.64^{* * *}$ & 1.20 & 1.21 & 1.04 & 1.12 & 1.28 & $1.53^{* * *}$ & $3.10^{* * *}$ & $\begin{array}{l}0.3 \mu \mathrm{M1} \\
2.93^{* * *}\end{array}$ \\
\hline 500 & & & $\begin{array}{c}2.06^{* * *} \\
\bullet \bullet\end{array}$ & $1.48^{* * *}$ & 1.05 & 1.15 & $1.30^{*}$ & $1.67^{* * *}$ & $\cdots$ & $\cdots$ \\
\hline 1000 & & & $\begin{array}{c}2.46^{* * *} \\
\bullet \bullet \bullet\end{array}$ & $\begin{array}{c}2.10^{* * *} \\
\ldots . .\end{array}$ & 1.17 & 1.24 & $1.53^{* * *}$ & $1.70^{* * *}$ & & \\
\hline
\end{tabular}

Values expressed as means \pm standard deviations from three independent experiments.

${ }^{*} P<0.05, * * * P<0.001$ compared with control incubation.

$\cdots P<0.001$ compared to $100 \mathrm{nM}$ insulin.

for second-phase secretion [48]. The underlying mechanisms involved in the $\mathrm{K}^{+}{ }_{\text {ATP }}$ channel-dependent pathway are well defined. In this pathway, glucose is transported into $\beta$ cells through facilitated diffusion of GLUT2 glucose transporters and this glucose undergoes metabolism to produce ATP molecules. The increase of intracellular ATP/ADP ratio results in the closure of the $\mathrm{K}^{+}$ATP channel and leads to depolarization of the membrane. This causes the opening of voltage-dependent calcium $\left(\mathrm{Ca}^{2+}\right)$ channels and facilitating extracellular $\mathrm{Ca}^{2+}$ influx into the $\beta$ cell. A rise in free cytosolic $\mathrm{Ca}^{2+}$ eventually activates an effectors system responsible for translocation of insulin-containing secretory granules to the plasma membrane and the exocytotic release of insulin [43, 48]. Meanwhile, mechanisms underlying the $\mathrm{K}^{+}{ }_{\text {ATP }}$ channelindependent pathway remain unclear. Two mechanisms have been suggested; the enhancement of the stimulatory effect of $\mathrm{Ca}^{2+}$ on the secretory process [43] and the changes of regulators of the $\mathrm{K}^{+}$ATP channel-independent pathway, adenine nucleotide concentration [42].

In the present study, hot aqueous extract of $F$. deltoidea stimulates insulin secretion significantly with the highest magnitude of stimulation 7.31-fold $(P<0.001)$ obtained at concentration of $1000 \mu \mathrm{g} / \mathrm{mL}$. This stimulation was greater than that of $1000 \mu \mathrm{M}$ glibenclamide. This suggests that $F$. deltoidea may contain water-soluble insulin-secreting compounds that are more potent than glibenclamide. Viability study had confirmed that hot aqueous extract did not influence BRIN BD11 cells. These observations suggest that the hot aqueous extract of $F$. deltoidea has the enormous potential to be developed as new oral hypoglycemic agents targeted on stimulation of insulin secretion. Ethanolic extract $(100 \mu \mathrm{g} / \mathrm{mL})$ and methanolic extract (all concentrations) induced an increased insulin secretion. However, both extracts were found toxic against BRIN BD11 cells. This could possibly be due to the presence of toxic compounds in both extracts which can damages subcellular organelles of the cells and lead to cell death [49]. Thus, the efficacy of ethanolic and methanolic extracts in stimulating insulin secretion may not be taken into account.
The $1000 \mu \mathrm{g} / \mathrm{mL}$ of hot aqueous extract was further evaluated for determination of mechanisms underlying its insulin secretory action. This concentration of extract was chosen because it possesses the highest insulin secretion property among all $F$. deltoidea extracts. The extract was incubated in the presence and absence of insulin secretion modulators such as the insulinotropic agonist (tolbutamide and IBMX), insulinotropic antagonist (diazoxide and verapamil), and depolarization concentration of $\mathrm{KCl}(30 \mathrm{mM})$. It was shown that $30 \mathrm{mM} \mathrm{KCl}$ stimulated basal insulin secretion whereas other modulators did not. This could possibly be due to that $30 \mathrm{mM} \mathrm{KCl}$ fully depolarized the plasma membrane, hence activate $\mathrm{Ca}^{2+}$ channel and trigger insulin release $[50,51]$. Tolbutamide, a hypoglycemic agent from sulphonylureas group, stimulated insulin release through $\mathrm{K}^{+}{ }_{\text {ATP }}$ channel-dependent pathway $[43,52,53]$. This drug acts by closing $\mathrm{K}^{+}{ }_{\text {ATP }}$ channel, depolarizing the plasma membrane, and stimulating the influx of $\mathrm{Ca}^{2+}$ through the activation of voltage-dependent calcium channels $[54,55]$. In this study, tolbutamide had augmented insulin-releasing effect of $1000 \mu \mathrm{g} / \mathrm{mL}$ of hot aqueous extract indicating that insulin-secretory action of the $1000 \mu \mathrm{g} / \mathrm{mL}$ of hot aqueous extract involved $\mathrm{K}^{+}{ }_{\text {ATP }}$ channel-dependent pathway [34]. IBMX, an inhibitor of phosphodiesterase, raised intracellular cAMP levels of pancreatic $\beta$ cells and enhanced insulin secretion at nonstimulatory glucose concentration [56]. In this study, IBMX did not potentiate insulin releasing effect of $1000 \mu \mathrm{g} / \mathrm{mL}$ of hot aqueous extract suggesting that insulin secretory action of the extract did not involve cAMP production [57], and thus it was not mediated through cAMP-activated pathway such as protein kinase A (PKA) pathway [58].

Diazoxide, an established opener of $\mathrm{K}^{+}$ATP channels, inhibited insulin release through activation (opening) of the $\mathrm{K}^{+}$ATP channels of the $\beta$ cells $[43,51,59]$. In this study, diazoxide had significantly inhibited insulin-releasing effects of $1000 \mu \mathrm{g} / \mathrm{mL}$ of hot aqueous extract, indicating that activation of $\mathrm{K}^{+}$ATP channel participated in the insulin secretory action of the extract. This observation again suggested that 
$\mathrm{K}^{+}$ATP channel-dependent pathway is involved in the insulin secretory action of the extract. It was shown that diazoxide inhibited but did not completely abolish the insulin-releasing effects of $1000 \mu \mathrm{g} / \mathrm{mL}$ hot aqueous extract. This suggested that, beside $\mathrm{K}^{+}$ATP channel-dependent pathway, the stimulatory action of the $1000 \mu \mathrm{g} / \mathrm{mL}$ of hot aqueous extract might also involve $\mathrm{K}^{+}$ATP channel-independent pathway [60]. This suggestion was supported by observation with $30 \mathrm{mM} \mathrm{KCl}$, a concentration that fully depolarized the cell membrane. Further potentiation of insulin release by $1000 \mu \mathrm{g} / \mathrm{mL}$ of hot aqueous extract under depolarized condition indicating that the extract also exerts insulin-secreting action through $\mathrm{K}^{+}{ }_{\text {ATP }}$ channel-independent manner $[50,51]$. In this study, the molecular mechanisms underlying $\mathrm{K}^{+}$ATP channel-independent pathway were not evaluated. It was reported that, under $\mathrm{K}^{+}{ }_{\text {ATP }}$ channel-independent pathway, insulin release was triggered through the enhancement of the stimulatory effect of $\mathrm{Ca}^{2+}$ on the secretory process [43] or changes adenine nucleotide concentration [42]. Verapamil is an L-type voltage-dependent $\mathrm{Ca}^{2+}$ channel (VDCC) blocker from phenylalkylamine classes. This drug inhibited insulin release by preventing $\mathrm{Ca}^{2+}$ influx into the cells through $\mathrm{L}$ type VDCC [61]. In this study, verapamil had significantly inhibited the insulin-releasing effects of $1000 \mu \mathrm{g} / \mathrm{mL}$ hot aqueous extract indicating that the insulin secretory action of the extract was dependent on extracellular $\mathrm{Ca}^{2+}$ that is acquired through activation of VDCC. It was shown that verapamil only inhibited but did not completely abolish insulin-releasing effects of $1000 \mu \mathrm{g} / \mathrm{mL}$ hot aqueous extract from BRIN BD11 cells indicating that insulin release also occurs in the absence of extracellular $\mathrm{Ca}^{2+}$. This suggests that the extract may have the ability to induce mobilization of stored intracellular $\mathrm{Ca}^{2+}$ to promote insulin release [34]. The other possible mechanism for ability of the extract to trigger insulin release in the presence of verapamil is the influx of $\mathrm{Ca}^{2+}$ occuring through other types of $\mathrm{Ca}^{2+}$ channel such as $\mathrm{N}$-type $\mathrm{Ca}^{2+}$ channel and voltage-operated $\mathrm{Ca}^{2+}$ channel (VOCC), thereby increased intracellular concentration of $\mathrm{Ca}^{2+}$ [62-64]. In this study, the effect of F. deltoidea extracts on insulin secretion was evaluated at basal glucose concentration $(2 \mathrm{mM})$ only, and no evaluation at high glucose concentration $(16.7 \mathrm{mM})$ was performed. So, it could not be concluded that insulin-secreting activity of $F$. deltoidea extracts is glucose-dependent. It was widely accepted that a good insulinotropic agent must be able to stimulate insulin secretion at both basal and elevated glucose concentrations [65].

Insulin was reported to increase glucose uptake in adipocytes cells $[35,66,67]$. The present study was in accord with such reports that $100 \mathrm{nM}$ insulin significantly increased glucose uptake by approximately 1.64-fold in 3T3F442A adipocyte cells. The same concentration of insulin was also used to stimulate glucose uptake in the presence of $F$. deltoidea extracts. This concentration of insulin was widely used to stimulate glucose uptake into adipocytes cells [68, 69]. In the present study, ethanolic (500 and $1000 \mu \mathrm{g} / \mathrm{mL}$ ) and methanolic extracts (500 and $1000 \mu \mathrm{g} / \mathrm{mL}$ ) significantly enhance basal (absence of $100 \mathrm{nM}$ insulin) glucose uptake. The enhancement of both extracts at concentration of
$1000 \mu \mathrm{g} / \mathrm{mL}$ was significantly higher than that of $100 \mathrm{nM}$ insulin alone indicating that such concentration of extracts enhances glucose uptake in an insulin-mimetic manner. Meanwhile, both extracts at concentrations of 100, 500, and $1000 \mu \mathrm{g} / \mathrm{mL}$ significantly enhance insulin-stimulated (presence of $100 \mathrm{nM}$ insulin) glucose uptake. It was shown that enhancement of $1000 \mu \mathrm{g} / \mathrm{mL}$ of ethanolic extract was significantly higher than that of $100 \mathrm{nM}$ insulin indicating that the extract enhances glucose uptake by sensitizing insulin action $[70,71]$. It was shown that $1000 \mu \mathrm{g} / \mathrm{mL}$ of ethanolic extract enhances glucose uptake by both mimicking and sensitizing insulin action. Many antidiabietic plants enhanced glucose uptake through the above mechanisms, for example, Lagerstroemia speciosa [35] and Agaricus campestris [33] have been reported to enhance glucose uptake in an insulin-mimetic manner, Salvia miltiorrhiza Bunge [72] through insulinsensitizing mechanisms, and Campsis grandiflora [73] and Vaccinium angustifolium [67] through both mechanisms. Rosiglitazone maleate at concentrations of $35 \mu \mathrm{M}$ (1.99fold) and $70 \mu \mathrm{M}$ (2.27-fold) were used as positive control to challenge glucose uptake activity of $F$. deltoidea extracts under basal and insulin-stimulated states, respectively. These concentrations were chosen because they produced highest enhancement effect after a dose-response evaluation. Rosiglitazone is an antidiabetic drug from thiazolidinedione (TZD) groups. This PPAR gamma agonist has been shown to enhance glucose uptake into adipocytes cells [74]. In this study, $1000 \mu \mathrm{g} / \mathrm{mL}$ of ethanolic and methanolic extracts which evoked an uptake of 2.04- and 1.97-fold, respectively exhibited a comparable potential of basal glucose uptake with $35 \mu \mathrm{M}$ rosiglitazone maleate. Under insulin-stimulated state, neither ethanolic extract nor methanolic extract exhibited comparable potential of glucose uptake activity with $70 \mu \mathrm{M}$ rosiglitazone maleate.

Beside stimulation of glucose uptake, insulin also was reported to stimulate adiponectin secretion from adipocytes cells $[75,76]$. Treatment of adipocytes cells with $160 \mathrm{nM}$ insulin increased adiponectin secretion by 2 -fold [77]. In the present study, $100 \mathrm{nM}$ insulin significantly stimulates adiponectin secretion from 3T3F442A adipocytes cells by 1.60 -fold. The hot aqueous extract (500 and $1000 \mu \mathrm{g} / \mathrm{mL}$ ) augments basal and insulin-stimulated adiponectin secretion significantly. It was found that basal secretion was higher than the insulin-stimulated secretion, and this suggests that adiponectin secretion activity of hot aqueous extract was independent of insulin. The $500 \mu \mathrm{g} / \mathrm{mL}$ of hot aqueous extract augments basal adiponectin secretion higher than $100 \mathrm{nM}$ insulin indicating that the extract augments adiponectin secretion in an insulin-mimetic manner [78]. Meanwhile, $1000 \mu \mathrm{g} / \mathrm{mL}$ of hot aqueous extract augments both basal and insulin-stimulated adiponectin secretion greater than that of $100 \mathrm{nM}$ insulin suggesting that this extract enhances adiponectin secretion by mimicking and sensitizing insulin action. Methanolic extract at higher concentrations (500 and $1000 \mu \mathrm{g} / \mathrm{mL}$ ) augments basal adiponectin secretion significantly whereas lower concentrations (10, 50, and $100 \mu \mathrm{g} / \mathrm{mL}$ ) did not affect basal adiponectin secretion. Meanwhile, insulin-stimulated adiponectin secretion was augmented at all concentrations of methanolic 
extract. Augmentation of adiponectin secretion by methanolic extract was lesser than that of $100 \mathrm{nM}$ insulin alone suggesting that the extract did not mimic or sensitize insulin action. Rosiglitazone maleate was used as positive control to challenge $F$. deltoidea extracts in augmenting adiponectin secretion from 3T3F442A adipocytes. TZD groups have been found to increase expression and synthesis of adiponectin in vitro and in vivo $[79,80]$. In addition, treatment of 3T3-L1 adipocytes with TZDs increased adiponectin secretion by $67-89 \%$ [79]. In this study, rosiglitazone maleate increased basal and insulin-stimulated adiponectin secretion by 3.10- and 2.93-fold, respectively. However, neither hot aqueous nor methanolic extracts augmented basal or insulinstimulated adiponectin secretion to a greater extent than that of rosiglitazone maleate indicating that potential of $F$. deltoidea in augmenting adiponectin secretion was lesser than rosiglitazone maleate. This could possibly be due to that such $F$. deltoidea extracts contain mixture of bioactive and nonbioactive compounds, and there is possibility that the non-bioactive would reduce the concentration of active compounds in the extract and decreased the ability of the extracts to stimulate adiponectin secretion. In contrast, the potential of rosiglitazone maleate which consists of single compound to stimulate adiponectin secretion from adipocytes cells has been scientifically proven [79].

This study had shown hot aqueous, ethanolic, and methanolic extracts of $F$. deltoidea stimulates insulin secretion from BRIN BD11 cells significantly. Nevertheless, insulinsecreting property of ethanolic and methanolic extracts could not be considered because such extracts were found toxic against BRIN BD11 cells. Mechanisms underlying insulin secretory action of hot aqueous extract involve both $\mathrm{K}^{+}$ATP channel-dependent and independent pathways. The extract also has the ability to induce the usage of intracellular $\mathrm{Ca}^{2+}$ to trigger insulin release. The ethanolic and methanolic extracts have the ability to enhance basal and insulinstimulated glucose uptake into adipocyte cells. The extracts possess either insulin-mimetic or insulin-sensitizing property or combination of both properties during enhancing glucose uptake into such cells. Ethanolic extract exhibited the higher potential of glucose uptake activity compared to methanolic extract whereas the hot aqueous extract has no effect on glucose uptake activity. Meanwhile, the hot aqueous and methanolic extracts augment basal and insulinstimulated adiponectin secretion from adipocyte cells. The hot aqueous extract exhibited higher adiponectin secretion activity as compared to methanolic extract whereas the ethanolic extract has no effect on adiponectin secretion activity.

In this study, it was shown that hot aqueous extract exhibited significant insulin secretion and adiponectin secretion activity but has no effect on glucose uptake activity while the ethanolic extract showed significant glucose uptake activity but has no effect on the former two activities. Meanwhile, the methanolic extract exhibited significant adiponectin secretion and glucose uptake activity but not insulin secretion activity. This could be due to the fact that each $F$. deltoidea extract possesses antidiabetic compounds which are unique for some activity only. For example, the hot aqueous extract may own antidiabetic compounds that exert its antidiabetic actions by stimulation of insulin secretion from pancreatic $\beta$ cells and augmentation of adiponectin secretion from adipocytes cells while the ethanolic extract may own antidiabetic compounds that exert its antidiabetic action by enhancement of glucose uptake in adipocytes cells only.

\section{Conclusions}

From this study, it was suggested that the antihyperglycemic actions of $F$. deltoidea are mediated through stimulation of insulin secretion from pancreatic $\beta$ cells, enhancement of glucose uptake by adipocytes cells, and augmentation of adiponectin secretion from adipocytes cells as well. The dual pancreatic and extrapancreatic actions of F. deltoidea illustrate the enormous potential of this plant to be developed as new oral antidiabetic drugs. Furthermore, the adiponectinsecreting and insulin-sensitizing properties of F. deltoidea indicated that this plant could ameliorate systemic insulin resistance and may potentially be beneficial for type 2 diabetes mellitus related to insulin resistance.

\section{Acknowledgments}

The authors wish to thank the Malaysian Nuclear Agency for providing grant for this research (Project no. MINT-R\&D06-19/02) and to the Universiti Putra Malaysia for providing technical support for this study.

\section{References}

[1] L. Guo and R. Tabrizchi, "Peroxisome proliferator-activated receptor gamma as a drug target in the pathogenesis of insulin resistance," Pharmacology \& Therapeutics, vol. 111, no. 1, pp. 145-173, 2006.

[2] M. S. Ahmad and N. Ahmed, "Antiglycation properties of aged garlic extract: possible role in prevention of diabetic complications," The Journal of Nutrition, vol. 136, no. 3, pp. 796S-799S, 2006.

[3] M. J. Fowler, "Microvascular and macrovascular complications of diabetes," Clinical Diabetes, vol. 26, no. 2, pp. 77-82, 2008.

[4] S. Wild, G. Roglic, A. Green, R. Sicree, and H. King, "Global prevalence of diabetes: estimates for the year 2000 and projections for 2030," Diabetes Care, vol. 27, no. 5, pp. 10471053, 2004.

[5] J. Kirchheiner, I. Roots, M. Goldammer, B. Rosenkranz, and J. Brockmöller, "Effect of genetic polymorphisms in cytochrome P450 (CYP) 2C9 and CYP2C8 on the pharmacokinetics of oral antidiabetic drugs: clinical relevance," Clinical Pharmacokinetics, vol. 44, no. 12, pp. 1209-1225, 2005.

[6] M. Wei, S. P. Gaskill, S. M. Haffner, and M. P. Stern, "Effects of diabetes and level of glycemia on all-cause and cardiovascular mortality: the san antonio heart study," Diabetes Care, vol. 21, no. 7, pp. 1167-1172, 1998.

[7] I. W. Campbell, "Antidiabetic drugs present and future: will improving insulin resistance benefit cardiovascular risk in type 2 diabetes mellitus?" Drugs, vol. 60, no. 5, pp. 1017-1028, 2000.

[8] J. M. Chehade and A. D. Mooradian, "A rational approach to drug therapy of type 2 diabetes mellitus," Drugs, vol. 60, no. 1, pp. 95-113, 2000. 
[9] C. R. Culy and B. Jarvis, "Repaglinide: a review of its therapeutic use in type 2 diabetes mellitus," Drugs, vol. 61, no. 11, pp. 1625-1660, 2001.

[10] P. B. Watkins and R. W. Whitcomb, "Hepatic dysfunction associated with troglitazone," The New England Journal of Medicine, vol. 338, no. 13, pp. 916-917, 1998.

[11] D. S. H. Bell, "Current status of diabetes treatment," Southern Medical Journal, vol. 95, no. 1, pp. 24-29, 2002.

[12] D. Puri, "The insulinotropic activity of a Nepalese medicinal plant biophytum sensitivum: preliminary experimental study," Journal of Ethnopharmacology, vol. 78, no. 1, pp. 8993, 2001.

[13] L. H. Bösenberg and D. G. Van Zyl, "The mechanism of action of oral antidiabetic drugs: a review of recent literature," Journal of Endocrinology, Metabolism and Diabetes of South Africa, vol. 13, no. 3, pp. 80-89, 2008.

[14] M. B. Patel and S. H. Mishra, "Cell lines in diabetes research: a review," Pharmacognosy Review, vol. 2, no. 4, pp. 188-205, 2008.

[15] U. B. Pajvani, X. Du, T. P. Combs et al., "Structurefunction studies of the adipocyte-secreted hormone Acrp30/ adiponectin: implications for metabolic regulation and bioactivity," Journal of Biological Chemistry, vol. 278, no. 11, pp. 9073-9085, 2003.

[16] Y. M. Tzeng, K. Chen, Y. K. Rao, and M. J. Lee, "Kaempferitrin activates the insulin signaling pathway and stimulates secretion of adiponectin in 3T3-L1 adipocytes," European Journal of Pharmacology, vol. 607, no. 1-3, pp. 27-34, 2009.

[17] A. H. Berg, T. P. Combs, X. Du, M. Brownlee, and P. E. Scherer, "The adipocyte-secreted protein Acrp30 enhances hepatic insulin action," Nature Medicine, vol. 7, no. 8, pp. 947-953, 2001.

[18] T. Kadowaki, T. Yamauchi, N. Kubota, K. Hara, K. Ueki, and $\mathrm{K}$. Tobe, "Adiponectin and adiponectin receptors in insulin resistance, diabetes, and the metabolic syndrome," The Journal of Clinical Investigation, vol. 116, no. 7, pp. 1784-1792, 2006.

[19] T. Yamauchi, J. Kamon, H. Waki et al., "The fat-derived hormone adiponectin reverses insulin resistance associated with both lipoatrophy and obesity," Nature Medicine, vol. 7, no. 8, pp. 941-946, 2001.

[20] Y. Fu, N. Luo, R. L. Klein, and W. T. Garvey, "Adiponectin promotes adipocyte differentiation, insulin sensitivity, and lipid accumulation," The Journal of Lipid Research, vol. 46, no. 7, pp. 1369-1379, 2005.

[21] A. Wiecek, M. Adamczak, and J. Chudek, "Adiponectinan adipokine with unique metabolic properties," Nephrology Dialysis Transplantation, vol. 22, no. 4, pp. 981-988, 2007.

[22] K. Mat-Salleh and A. Latif, "Dikotiledon: subkelas hamamelidae. Ficus deltoidea jack," in Tumbuhan Ubatan Malaysia, pp. 184-185, Pusat Pengurusan Penyelidikan, Universiti Kebangsaan Malaysia, 2002.

[23] M. R. Sulaiman, M. K. Hussain, Z. A. Zakaria et al., "Evaluation of the antinociceptive activity of Ficus deltoidea aqueous extract," Fitoterapia, vol. 79, no. 7-8, pp. 557-561, 2008.

[24] Z. Adam, M. Hamid, A. Ismail, and S. Khamis, "Effect of Ficus deltoidea extracts on hepatic basal and insulin-stimulated glucose uptake," Journal of Biological Sciences, vol. 9, no. 2, pp. 9-16, 2009.

[25] Z. Adam, M. Hamid, A. Ismail, S. Khamis, and N. Marsidi, "Antihyperglycemic and glucose tolerance activity of Ficus deltoidea ethanolic extract in diabetic rats," Malaysian Journal of Health Sciences, vol. 8, no. 1, pp. 25-30, 2010.
[26] Z. Adam, A. Ismail, S. Khamis, M. M. H. Mohd, and M. Hamid, "Antihyperglycemic activity of Ficus deltoidea ethanolic extract in normal rats," Sains Malaysiana, vol. 40, no. 5, pp. 497-503, 2011.

[27] Z. Adam, M. Hamid, A. Ismail, and S. Khamis, "Antihyperglycemic property of Ficus deltoidea hot aqueous extract in STZ-induced diabetic rats," in Proceedings of the 25th Scientific Meeting of the Malaysian Society of Pharmacology and Physiology, University Putra Malaysia, Malaysia, May 2011.

[28] Z. Adam, M. Hamid, A. Ismail, and S. Khamis, "Effect of Ficus deltoidea extracts on hepatic basal and insulin-stimulated glucose uptake," Journal of Biological Sciences, vol. 9, no. 8, pp. 796-803, 2009.

[29] Z. Adam, S. Khamis, A. Ismail, and M. Hamid, "Inhibitory properties of Ficus deltoidea on $\alpha$-glucosidase activity," Research Journal of Medicinal Plant, vol. 4, no. 2, pp. 61-75, 2010.

[30] T. Mosmann, "Rapid colorimetric assay for cellular growth and survival: application to proliferation and cytotoxicity assays," Journal of Immunological Methods, vol. 65, no. 1-2, pp. 55-63, 1983.

[31] J. Carmichael, W. G. DeGraff, and A. F. Gazdar, "Evaluation of a tetrazolium-based semiautomated colorimetric assay: assessment of chemosensitivity testing," Cancer Research, vol. 47, no. 4, pp. 936-942, 1987.

[32] N. H. McClenaghan, C. R. Barnett, E. Ah-Sing et al., "Characterization of a novel glucose-responsive insulin-secreting cell line, BRIN-BD11, produced by electrofusion," Diabetes, vol. 45, no. 8, pp. 1132-1140, 1996.

[33] A. M. Gray and P. R. Flatt, "Insulin-releasing and insulinlike activity of agaricus campestris (mushroom)," Journal of Endocrinology, vol. 157, no. 2, pp. 259-266, 1998.

[34] J. Hannan, L. Marenah, L. Ali, B. Rokeya, P. R. Flatt, and Y. H. A. Abdel-Wahab, "Ocimum sanctum leaf extracts stimulate insulin secretion from perfused pancreas, isolated islets and clonal pancreatic $\beta$-cells," Journal of Endocrinology, vol. 189, no. 1, pp. 127-136, 2006.

[35] F. Liu, J. Kim, Y. Li, X. Liu, J. Li, and X. Chen, "An extract of Lagerstroemia speciosa L. has insulin-like glucose uptakestimulatory and adipocyte differentiation-inhibitory activities in 3T3-L1 cells," Journal of Nutrition, vol. 131, no. 9, pp. 22422247, 2001.

[36] B. W. Roffey, A. S. Atwal, T. Johns, and S. Kubow, "Water extracts from momordica charantia increase glucose uptake and adiponectin secretion in 3T3-L1 adipose cells," Journal of Ethnopharmacology, vol. 112, no. 1, pp. 77-84, 2007.

[37] C. S. Hii and S. L. Howell, "Effects of flavonoids on insulin secretion and ${ }^{45} \mathrm{Ca}^{2+}$ handling in rat islets of langerhans," Journal of Endocrinology, vol. 107, no. 1, pp. 1-8, 1985.

[38] M. Pinent, M. Blay, M. C. Bladé, M. J. Salvadó, L. Arola, and A. Ardévol, "Grape seed-derived procyanidins have an antihyperglycemic effect in streptozotocin-induced diabetic rats and insulinomimetic activity in insulin-sensitive cell lines," Endocrinology, vol. 145, no. 11, pp. 4985-4990, 2004.

[39] A. M. Gray and P. R. Flatt, "Antihyperglycemic actions of eucalyptus globulus (eucalyptus) are associated with pancreatic and extra-pancreatic effects in mice," The Journal of Nutrition, vol. 128, no. 12, pp. 2319-2323, 1998.

[40] A. Zunoliza, S. Khalid, I. Zhari et al., "Evaluation of extracts of leaf of three Ficus deltoidea varieties for antioxidant activities and secondary metabolites," Pharmacognosy Research, vol. 1, no. 4, pp. 216-223, 2009.

[41] E. Elmore, S. Siddiqui, N. Desai, M. P. Moyer, V. E. Steele, and J. L. Redpath, "The human epithelial cell cytotoxicity assay for 
determining tissue specific toxicity: method modifications," Methods in Cell Science, vol. 24, no. 4, pp. 145-153, 2003.

[42] Y. Sato and J. C. Henquin, "The $\mathrm{K}^{+}{ }_{\text {ATP }}$ channel-independent pathway of regulation of insulin secretion by glucose: in search of the underlying mechanism," Diabetes, vol. 47, no. 11, pp. 1713-1721, 1998.

[43] M. Gembal, P. Gilon, and J. C. Henquin, "Evidence that glucose can control insulin release independently from its action on ATP-sensitive $\mathrm{K}^{+}$channels in mouse B cells," The Journal of Clinical Investigation, vol. 89, no. 4, pp. 1288-1295, 1992.

[44] A. R. Saltiel and J. E. Pessin, "Insulin signaling pathways in time and space," Trends in Cell Biology, vol. 12, no. 2, pp. 65$71,2002$.

[45] S. E. Leney and J. M. Tavaré, "The molecular basis of insulinstimulated glucose uptake: signalling, trafficking and potential drug targets," Journal of Endocrinology, vol. 203, no. 1, pp. 1$18,2009$.

[46] P. H. Ducluzeau, L. M. Fletcher, H. Vidal, M. Laville, and J. M. Tavaré, "Molecular mechanisms of insulin-stimulated glucose uptake in adipocytes," Diabetes \& Metabolism, vol. 28, no. 2, pp. 85-92, 2002.

[47] Y. J. Liu, H. Cheng, H. Drought, M. J. MacDonald, G. W. G. Sharp, and S. G. Straub, "Activation of the $\mathrm{K}_{A T P}$ channelindependent signaling pathway by the nonhydrolyzable analog of leucine, BCH," American Journal of Physiology - Endocrinology and Metabolism, vol. 285, no. 2, pp. E380-E389, 2003.

[48] S. G. Straub and G. W. Sharp, "Glucose-stimulated signaling pathways in biphasic insulin secretion," Diabetes/Metabolism Research and Reviews, vol. 18, no. 6, pp. 451-463, 2002.

[49] K. C. C. Sabino, C. R. M. Gayer, L. C. A. Vaz, L. R. L. Santos, I. Felzenszwalb, and M. G. P. Coelho, "In vitro and in vivo toxicological study of the Pterodon pubescens seed oil," Toxicology Letters, vol. 108, no. 1, pp. 27-35, 1999.

[50] N. H. McClenaghan, P. R. Flatt, and C. J. Bailey, "Insulinreleasing action of the novel antidiabetic agent BTS 67 582," British Journal of Pharmacology, vol. 123, no. 3, pp. 400-404, 1998.

[51] A. M. Gray, Y. H. Abdel-Wahab, and P. R. Flatt, "The traditional plant treatment, Sambucus nigra(elder), exhibits insulin-like and insulin-releasing actions in vitro," The Journal of Nutrition, vol. 130, no. 1, pp. 15-20, 2000.

[52] J. L. Evans and R. J. Rushakoff, "Oral pharmacological agents for type 2 diabetes: sulfonylureas, meglitinides, metformin, thiazolidinediones, $\alpha$-glucosidase inhibitors, and emerging approaches," http://www.endotext.org/diabetes/diabetes16/ diabetes $16 . h$ htm.

[53] J. M. Chehade and A. D. Mooradian, "A rational approach to drug therapy of type 2 diabetes mellitus," Drugs, vol. 60, no. 1, pp. 95-113, 2000.

[54] P. Mariot, P. Gilon, M. Nenquin, and J. C. Henquin, “Tolbutamide and diazoxide influence insulin secretion by changing the concentration but not the action of cytoplasmic $\mathrm{Ca}^{2+}$ in $\beta$-cells," Diabetes, vol. 47, no. 3, pp. 365-373, 1998.

[55] V. Kecskemeti, Z. Bagi, P. Pacher, I. Posa, E. Kocsis, and M. Z. Koltai, "New trends in the development of oral antidiabetic drugs," Current Medicinal Chemistry, vol. 9, no. 1, pp. 53-71, 2002.

[56] E. G. Siegel, C. B. Wollheim, and M. Kikuchi, "Dependency of cyclic AMP-induced insulin release on intra- and extracellular calcium in rat islets of langerhans," The Journal of Clinical Investigation, vol. 65, no. 2, pp. 233-241, 1980.

[57] J. M. Hannan, L. Marenah, L. Ali, B. Rokeya, P. R. Flatt, and Y. H. Abdel-Wahab, "Insulin secretory actions of extracts of asparagus racemosus root in perfused pancreas, isolated islets and clonal pancreatic $\beta$-cells," Journal of Endocrinology, vol. 192, no. 1, pp. 159-168, 2007.

[58] H. Yajima, M. Komatsu, T. Schermerhorn et al., "cAMP enhances insulin secretion by an action on the ATP-sensitive $\mathrm{K}^{+}$channel-independent pathway of glucose signaling in rat pancreatic islets," Diabetes, vol. 48, no. 5, pp. 1006-1012, 1999.

[59] N. K. Hoa, A. Norberg, R. Sillard et al., "The possible mechanisms by which phanoside stimulates insulin secretion from rat islets," Journal of Endocrinology, vol. 192, no. 2, pp. 389-394, 2007.

[60] J. N. Mathews, P. R. Flatt, and Y. H. Abdel-Wahab, “Asparagus adscendens (Shweta musali) stimulates insulin secretion, insulin action and inhibits starch digestion," British Journal of Nutrition, vol. 95, no. 3, pp. 576-581, 2006.

[61] P. Lebrun, M. H. Antoine, R. Ouedraogo et al., "Verapamil, a phenylalkylamine $\mathrm{Ca}^{2+}$ channel blocker, inhibits ATPsensitive $\mathrm{K}^{+}$channels in insulin-secreting cells from rats," Diabetologia, vol. 40, no. 12, pp. 1403-1410, 1997.

[62] R. Vajna, U. Klöckner, A. Pereverzev et al., "Functional coupling between "R-type" $\mathrm{Ca}^{2+}$ channels and insulin secretion in the insulinoma cell line INS-1," European Journal of Biochemistry, vol. 268, no. 4, pp. 1066-1075, 2001.

[63] L. S. Satin, S. J. Tavalin, T. A. Kinard, and J. Teague, "Contribution of L- and non-L-type calcium channels to voltage-gated calcium current and glucose-dependent insulin secretion in HIT-T15 cells," Endocrinology, vol. 136, no. 10, pp. 4589-4601, 1995.

[64] B. Liu, H. Asare-Anane, A. Al-Romaiyan et al., "Characterisation of the insulinotropic activity of an aqueous extract of Gymnema sylvestre in mouse $\beta$-cells and human islets of langerhans," Cellular Physiology and Biochemistry, vol. 23, no. 1-3, pp. 125-132, 2009.

[65] S. Efendic, A. M. Efanov, P. O. Berggren, and S. V. Zaitsev, "Two generations of insulinotropic imidazoline compounds," Diabetes, vol. 51, supplement 3, pp. S448-S454, 2002.

[66] Y. Kang and H. Y. Kim, "Glucose uptake-stimulatory activity of Amomi Semen in 3T3-L1 adipocytes," Journal of Ethnopharmacology, vol. 92, no. 1, pp. 103-105, 2004.

[67] L. C. Martineau, A. Couture, D. Spoor et al., "Anti-diabetic properties of the Canadian lowbush blueberry Vaccinium angustifolium ait," Phytomedicine, vol. 13, no. 9-10, pp. 612623, 2006.

[68] D. Konrad, P. J. Bilan, Z. Nawaz et al., "Need for GLUT4 activation to reach maximum effect of insulin-mediated glucose uptake in brown adipocytes isolated from GLUT4mycexpressing mice," Diabetes, vol. 51, no. 9, pp. 2719-2726, 2002.

[69] K. Sakurai, M. Kawazuma, T. Adachi et al., "Bisphenol A affects glucose transport in mouse 3T3-F442A adipocytes," British Journal of Pharmacology, vol. 141, no. 2, pp. 209-214, 2004.

[70] B. S. Ko, S. B. Choi, S. K. Park, J. S. Jang, Y. E. Kim, and S. Park, "Insulin sensitizing and insulinotropic action of berberine from Cortidis Rhizoma," Biological \& Pharmaceutical Bulletin, vol. 28, no. 8, pp. 1431-1437, 2005.

[71] A. Benhaddou-Andaloussi, L. C. Martineau, D. Spoor et al., "Antidiabetic activity of Nigella sativa seed extract in cultured pancreatic $\beta$-cells, skeletal muscle cells, and adipocytes," Pharmaceutical Biology, vol. 46, no. 1-2, pp. 96-104, 2008.

[72] S. H. Jung, H. J. Seol, S. J. Jeon, K. H. Son, and J. R. Lee, "Insulin-sensitizing activities of tanshinones, diterpene compounds of the root of Salvia miltiorrhiza bunge," Phytomedicine, vol. 16, no. 4, pp. 327-335, 2009. 
[73] S. H. Jung, Y. J. Ha, E. K. Shim et al., "Insulin-mimetic and insulin-sensitizing activities of a pentacyclic triterpenoid insulin receptor activator," Biochemical Journal, vol. 403, no. 2, pp. 243-250, 2007.

[74] C. Nugent, J. B. Prins, J. P. Whitehead et al., "Potentiation of glucose uptake in 3T3-L1 adipocytes by PPAR $y$ agonists is maintained in cells expressing a PPAR $\gamma$ dominant-negative mutant: evidence for selectivity in the downstream responses to PPAR $\gamma$ activation," Molecular Endocrinology, vol. 15, no. 10, pp. 1729-1738, 2001.

[75] P. E. Scherer, S. Williams, M. Fogliano, G. Baldini, and H. F. Lodish, "A novel serum protein similar to $\mathrm{C} 1 \mathrm{q}$, produced exclusively in adipocytes," The Journal of Biological Chemistry, vol. 270, no. 45, pp. 26746-26749, 1995.

[76] H. Motoshima, X. Wu, M. K. Sinha et al., "Differential regulation of adiponectin secretion from cultured human omental and subcutaneous adipocytes: effects of insulin and rosiglitazone," Journal of Clinical Endocrinology \& Metabolism, vol. 87, no. 12, pp. 5662-5667, 2002.

[77] J. S. Bogan and H. F. Lodish, "Two compartments for insulin-stimulated exocytosis in 3T3-L1 adipocytes defined by endogenous ACRP30 and GLUT4," The Journal of Cell Biology, vol. 146, no. 3, pp. 609-620, 1999.

[78] M. J. Lee, Y. K. Rao, K. Chen, Y. C. Lee, and Y. M. Tzeng, “Effect of flavonol glycosides from Cinnamomum osmophloeum leaves on adiponectin secretion and phosphorylation of insulin receptor- $\beta$ in 3T3-L1 adipocytes," Journal of Ethnopharmacology, vol. 126, no. 1, pp. 79-85, 2009.

[79] N. Maeda, M. Takahashi, T. Funahashi et al., "PPAR $\gamma$ ligands increase expression and plasma concentrations of adiponectin, an adipose-derived protein," Diabetes, vol. 50, no. 9, pp. 2094 2099, 2001.

[80] N. Stefan and M. Stumvoll, "Adiponectin-its role in metabolism and beyond," Hormone and Metabolic Research, vol. 34, no. 9, pp. 469-474, 2002. 


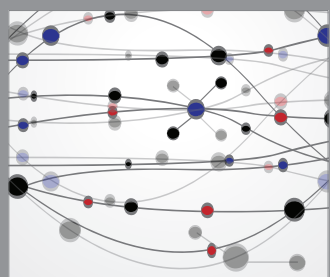

The Scientific World Journal
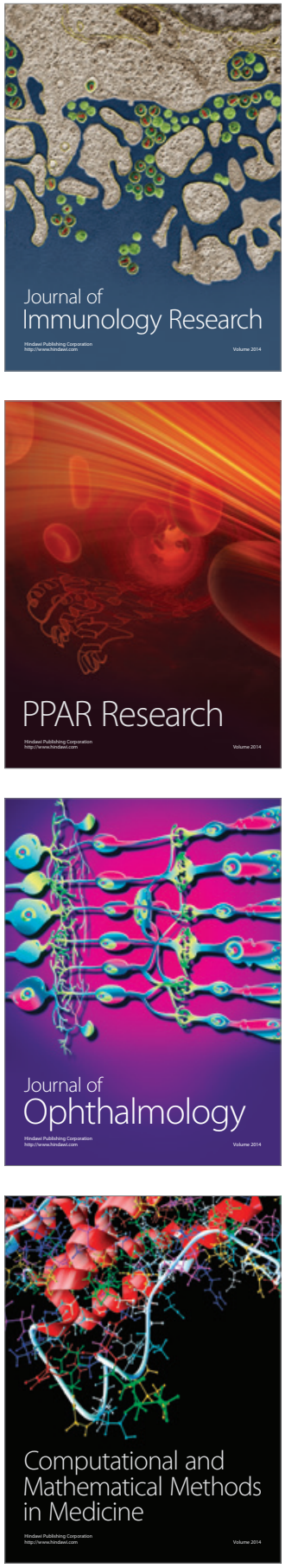

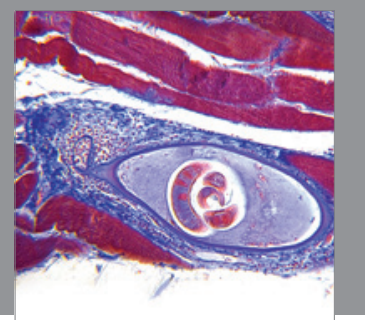

Gastroenterology

Research and Practice
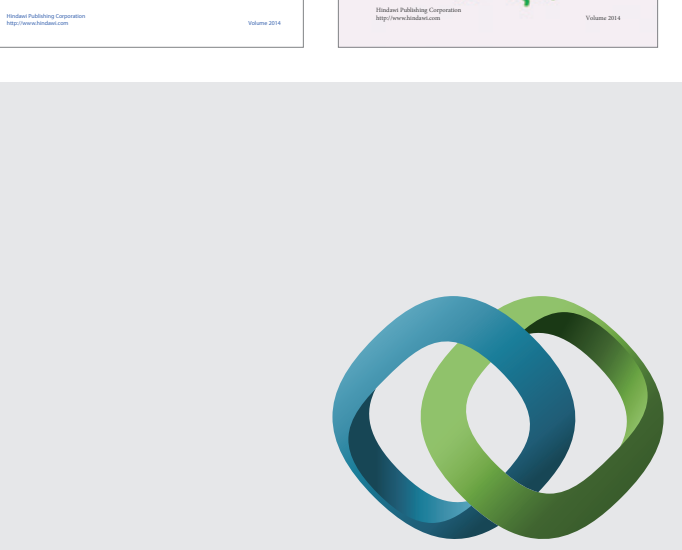

\section{Hindawi}

Submit your manuscripts at

http://www.hindawi.com
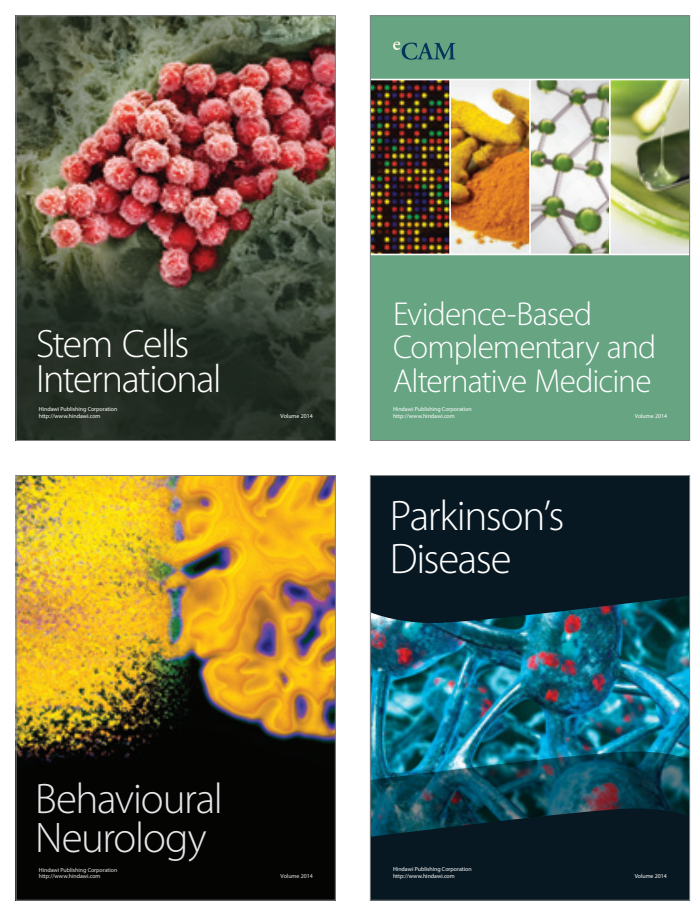

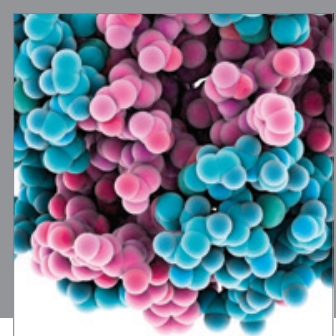

Journal of
Diabetes Research

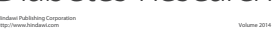

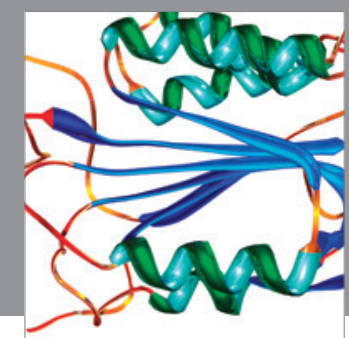

Disease Markers
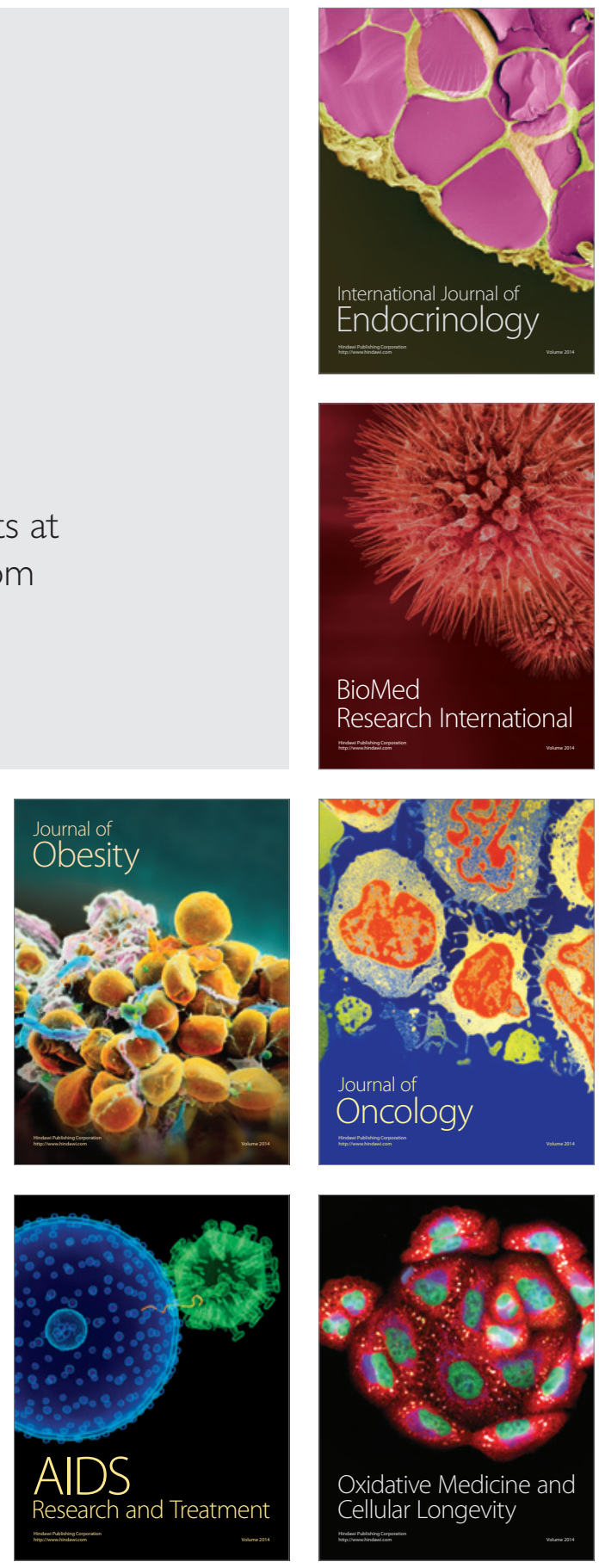